University of Rhode Island

DigitalCommons@URI

Open Access Dissertations

1966

\title{
The Effects of Selected Variables on the Microencapsulation of Solids
}

Louis A. Luzzi

University of Rhode Island

Follow this and additional works at: https://digitalcommons.uri.edu/oa_diss

\section{Recommended Citation}

Luzzi, Louis A., "The Effects of Selected Variables on the Microencapsulation of Solids" (1966). Open Access Dissertations. Paper 156.

https://digitalcommons.uri.edu/oa_diss/156

This Dissertation is brought to you for free and open access by DigitalCommons@URI. It has been accepted for inclusion in Open Access Dissertations by an authorized administrator of DigitalCommons@URI. For more information, please contact digitalcommons-group@uri.edu. 
THE EFFECTS OF SELECTED VARIABIES ON THE

MICROENCAPSULATION

OF SOLIDS

BY

LOUIS A. LUZZI

A THESIS SUBMITTED IN PARTIAL FULFILLMEN'T OF THE REQUIRMENTS FOR THE DEGREE OF

DOCTOR OF PHILOSOPHY

IN

PHARMACEUTICAL SCIENCES

UNIVERSITY OF RHODE ISLAND

1966 
TITLE: ABSTRACT

EFFECT OF VARIABLES

ON

MICROCAPSULES 


\begin{abstract}
A.BSTRACT
The hypothesis that solid particles may be encapsulated by coacervation led to the investigation of the extractability of microcapsules, which contained solids, by gastrointestinal fluids. Starting $\mathrm{pH}$, starting temperature, ratio of solid to encapsulating materials, quantity of denaturant, and final pH were varied. In addition a surfactant and dispersant were added to selected $g \in$ ries. The effecis of the variables and additives on microcapules were determined by submitting samples to simulated gastrointestinal fluids for periods of up to two and one-half hours and then comparing the extracts spectrophotometrically to know absorption spectra. Results showed that all variables and additives effected some degree of change in microcapsules.
\end{abstract}


TABLE OF CONTENTS

PAGE

ABSTRACT . . . . . . . . . . . . . . . iii

TABLE OF CONTENTS . . . . . . . . . . . . . . . 1

LIST OF TABLES . . . . . . . . . . . . . . . 3

LIST OF ILLUSTRATIONS AND PHOTOGRAPHS . . . . 5

I. INTRODUCTION . . . . . . . . . . 6

II. EXPERIMENTAL . . . . . . . . . . . 13

Preparation of Microcapsules . . . . . 13

Choice of Solids and Other Materials . . . 15

Method of Evaluation of Microcapsule

Strength . . . . . . . . . . 18

III. RESULTS . . . . . . . . . . . . . . . 24

Effect of Starting $\mathrm{pH}$ on Microcapsules . . . 24

Effect of Starting Temperature on Micro-

capsules . . . . . . . . . 26

Effect of Ratio of Pentobarbituric Acid

to Encapsulating Materials . . . . . . 26

Effect of Different Quantities of

Formaldehyde on Microcapsules . . . , 30

Effect of Final pH on Microcapsules . . . . 33

Effect of Tween 20 on Microcapsules . . . 38 
PAGE

Effect of Darvan 7 on Microcapsules . . .

Formulation of Fast and Slow Release

Microcapsules . . . . . . . . .

Microphotography of Microcapsules . . . .

IV. DISCUSSION • • • • • • • • • • • 53

Effect of Starting pH on Microcapisules . .

Effect of Starting Temperature on Microcapsules . . . . . . . . . . 56

Effect of the Ratio of Fentobarkiturio

Acid to Encapsulating Materials . . .

Effect of Formaldekyde on Microcapsules . . . . . . . . . 58

Effect of Final pH on Microcapsulss . . . . 60

V. CONCLUSIONS • • • • • • • • • • • 62

VI. REFERENCES . . . . . . . . . . . . 64 


\section{LIST OF TABLES}

TABLE

PAGE

I. Effect of Starting $\mathrm{pH}$ on the \% of Pentobarbituric Acid Extracted from Microcapsules Exposed to Gastrointestinal Fluids . . . . . . . .

II. Effect of Starting $\mathrm{pH}$ on the \% of Pentobarbituric Acid Extracted from Microcapsules Exposed to Intestinal Fluids . . . . . . . . . . . .

III. Effect of Starting Temperature on the \% of Pentobarbituric Acid Extracted from Microcapsules Exposed to Gastrointestinal Fluids . . . . . .

IV. Effect of Starting Temperature on the \% of Pentobarbituric Acid Extracted from Microcapsules Exposed to Intestinal Fluids . . . . . . . . .

V. Effect of Ratio on the \% of Pentobarbituric Acid Extracted from Microcapsules Exposed to Gastrointestinal Fluids . . . . . . . . .

VI. Effect of Ratio on the \% of Pentobarbituric Acid Extracted from Microcapsules Exposed to Intestinal Fluid . . . . . . . . . . . .

VII. Effect of Formaldehyde on the \% of Pentobarbituric Acid Extracted from Microcapsules Exposed to Gastrointestinal Fluids . . . . . . . . .

VIII. Effect of Formaldehyde on the \% of Pentobarbituric Acid Extracted from Microcapsules Exposed to Intestinal Fluids . . . . . . . . . . .

IX. Effect of Final pH on the \% of Pentobarbituric Acid Extracted from Microcapsules Exposed to Gastrointestinal Fluid . . . . . . . . . . . . 
TABLE

X. Effect of Final pH on the \% of Pentobarbituric Acid Extracted from Microcapsules Exposed to Intestinal Fluid . . . . . . . . . . . .

XI. Effect of Tween 20 on the \% of Pentobarbituric Acid Extracted from Microcapsules Exposed to Gastrointestinal Fluids . . . . . . . . .

XII. Effect of Darvan 7 on the $\%$ of Pertobarbituria Acid Extracted from Microcapsules Exposed to Gastrointestinal Fluids . . . . . . . . .

XIII. Effect of Darvan 7 on the \% of Pentobarbituric Acid Extracted from Microcapsules Exposed to Gastrointestinal Fluids . . . . . . . . . .

XIV. Effect of Darvan 7 on the $\%$ of Pentobarbituric Acid Extracted from Microcapsules Exposed to Gastrointestinal Fluids . . . . . . . . 


\section{LIST OF ILLUSTRATIONS}

AND PHOTOGRAPHS

\section{ILLUSTRATIONS:}

FIGURE

PAGE

1. Beer's Law Plot of Sodium Pentobarbital in $1 \%$ Gastric Fluid at $\mathrm{pH} 9.2$. . . . . .

2. Beer's Law Plot of Sodium Pentobarbital in $1 \%$ Intestinal Fluid at $\mathrm{pH} 9.2$. . . . .

3. Beer's Law Plot of Sodium Fentoharbital in $1 \%$ Solution of Empty Capsules Ground in a Vitris "45" Blender . . . . . . . . . .

\section{PHOTOGRAPHS}

1.

2.

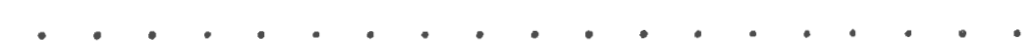

3.

4.

5.

6.

7. 


\section{INTRODUCTION}

The term coacervation has had a long and diversified history. It was used as early as 1398 to mean, "a 'heaping together,' either of people or things' (1). It has more recently been adopted by chemists to describe the salting out of a lyophilic solid into liquid droplets rather than solid aggregates (2). The term was first introduced into colloidal chemistry by Kruyt and Bungenberg de Jong (3) to describe the flocculation or separation of liquids from solution when at least one of the liquids contained a macromolecular or colloidal solute.

Coacervation has been sub-divided by Bungenberg de Jong (4) into simple coacervation and complex coacervation; simple coacervation describes a system which requires that only one colloidal solute be present, while complex coacervation describes a system containing more than one colloid.

According to this same author (5) simple coacervation is the aggregation or flocculation of a dispersed hydrophilic colloid brought about by the addition of a strongly hydrophilic substance, to produce a water deficit in a part of the system. Simple coacervation can be accomplished by mixing two colloidal dispersions each of which contains a concentration of colloid from approximately 20 to 40 per cent; or it can be induced in a dispersion of a less concentrated, single 
colloid by adding alcohol, sodium sulfate, or resorcinol. In either case, it is possible to redisperse the aggregated colloidal droplets by the addition of water. Neither the is oelectric point of the colloid nor the presence of indifferent salts is of any significance to the process of simple coacervation; the principal requirement here is merely the creation of an insufficiency of water in a part of the total system (6).

Complex coacervation can be induced in systems having two dispersed hydrophilic colloids of opposite electrical charges. Bungenberg de Jong stated that, in a system of gum arabic and gelatin, complex coacervation always occurs at $\mathrm{pH}$ values below the isoelectric point of the gelatin and maintained that this was true "however one changes the other factors" (7).

He explained that the apparent equivalent weight of the gelatin and gum arabic depended on the isoelectric point of the gelatin and the $\mathrm{pH}$ of the system (derived from the dissociation of the carboxyl groups). The optimum $\mathrm{pH}$ for complex coacervation was that $\mathrm{pH}$ at which equivalents of oppositely charged micelles were present, since at that point the greatest possible number of salt bonds were formed and the highest degree of coacervation occurred. Therefore, in such a system, the pH should be adjusted so that the gelatin particles are positive, since gum arabic particles are always negative in colloidal dispersion (8).

It was also observed that the practical limits of concentration of each colloid, within which complex coacervation occurred, were between 0.001 and 5 per cent (9). The upper limit was explained by the 
presence of the indifferent salt, calcium chloride, derived from calcium and chloride ions present in acacia and gelatin, respectively. Indifferent salts, such as calcium chloride, hinder coacervation because of the "double valency rule" (10).

Although simple and complex coacervation yield essentially the same type of products, the conditions necessary for the agglomeration of each of them differ considerably. When all of the factors are considered, the principal condition for simple coacervation becomes an insufficiency of water in part of the system. Complex coacervation, however, will not occur even if the concentration of colloids falls within the prescribed limits and the indifferent salt concentration is sufficiently low. The principal condition required for complex coacervation is adequate opposition of charge between two colloids, which can be brought about by adjustment of $\mathrm{pH}$. Minimal hydration of ions, the required condition for simple coacervation, is accomplished by the removal of water. Since $\mathrm{pH}$ can be precisely adjusted, and since the hydration process is more difficult to control, this study was concerned primarily with microencapsulation using complex coacervation.

Green and Schleicker (11) have made practical use of coacervation in a patented process of microencapsulation. In this process, capsules were formed either by the reaction of two oppositely charged dispersed colloids or by precipitation of one dispersed colloid through the action of a strongly hydrophilic substance. Although encapsulation using a 
single colloid was not carried out experimentally, it should be noted that procedures for such entrapment are to be found in the United States Patents: No. 2,730,457 (11), No. 2,712,507 (12), No. 2,730,456 (13), No. 2,800,456 (14), No. $28,800,458$ (15), No. 3, 137,631 (16), and No. 3, 155, 590 (17).

Various patents issued to Green and Schleicker $(13,18)$ indicate that paraffin oil, castor oil, sperm oil, lard oil, methyl salicylate, and trichlor odiphenyl have been entrapped in gelatin-acacia microcapsules. At least some of the oils contained dissolved substances, such as Sudan III dye, crystal violet lactone, malachite green lactone, and benzoyl leuco methylene blue. It is interesting to note that these patent holders claimed to be able to coacervate with concentrations of gelatin and gum arabic up to 14 per cent. The ability to coacervate at concentrations in excess of 5 per cent may have been due in part to the nucleating power of the oil droplets present in this system, which were not present in the Bungenberg de Jong system.

The process by which oils were encapsulated by Green and Schleicker was relatively simple. Dispersions of gelatin and acacia in water were made at $55^{\circ} \mathrm{C}$. and the $\mathrm{pH}$ of each was adjusted to a value just below the isoelectric point of the gelatin. An oil-in-water emulsion was then formed using the acacia and/or gelatin dispersions as the emulsifying medium. When only one of the colloidal dispersions was included in the emulsifying medium, the second dispersion was 
added following completion of emulsification. Then, the pH was adjusted to a value even farther below the isoelschric point of the gelatin and a solution of formaldehyde in water was added. Then, the temperature was reduced from $50^{\circ} \mathrm{C}$. to $10^{\circ} \mathrm{C}$. and the $\mathrm{pH}$ ras raised to a value above the isoelectric point of the gelatin. The viscosity was adjusted by evaporation or by addition of water, to prepare the product for its ultimate use. The authors pointed out that the product could be prepared as a free flowing powder, eithez by spray or oven drying. Conditions for encapsulation of oils other than those mentioned above were not given, nor was a method to evaluate the strength or degree of encapsulation elucidated (11, 13).

Luzzi and Gerraughty (18), in a study to determine the permeability of the capsule wall, assayed microcapsules containing modified mineral oil. The mineral oil was modified so that it possessed a range of saponification values and acid values, as well as surfactant properties. The samples were extracted, for varying periods of time, using ethyl ether; the liquid extracts were diluted with the solvent and assayed for oil content by spectrophotometric means. It was found that, although saponification value had little effect upon the permeability of the capsule wall, higher acid values and surfactants increased wall permeability.

Miller and Anderson (17), using a system of syclohexane, butyl rubber, aspirin, and ethyl cellulose prepared a sustained action, solid 
dosage form of aspirin. The authors claim a $92 \%$ aspirin content for their product; however, the assay method they used was not disclosed. This system may be thought of as encapsulation by means of simple coacervation, since it relied on the solubility of the encapsulating agent as a function of variable temperature. The authors have controlled the apparent required amount of solvent through variation of temperature as Bungenberg de Jong controlled available water by salt content.

Phares and Speradino (19), in a surmary, state, "Almost any insoluble particle can be coated with coacervate drops." The authors of Microcapsulation (20) enumerate several solid and liquid materials which have been encapsulated by coacervation. None of these sources, however, makes an attempt at predicting the rate at which the encapsulated substance will be released.

In pharmacy, as well as in other areas (20), encapsulation through coacervation has great potential practical application. Some properties of these microcapsules which would be especially useful to pharmacy include: the ability to prevent vaporization of any volatile substances (e.g., peppermint oil); the ability to protect moisture sensitive and light sensitive substances (e.g., vitamins $A$ and $K$ ); the ability to separate physically incompatible materials within a single system; the ability to disperse water-inscluble substances more readily in an aqueous medium; and, the ability to prolong the action 
of certain drugs when they have been ingested.

The effectiveness of a drug is dependent, above all, upon its availability to the body. A subsiance which is encapsulased is not immediately available. The capsule wall must be penetrated or must be conducive to a leaching action, or both. In either case, deviations from the prescribed method of microcapsule manufacture, along with suitable assay methods, should be investigated and the results considered when a pharmaceutical dose form is to be prepared. This is especially applicable when the drug is to be embodied in a sustained or prolonged release type of medication.

With these considerations in mind, the systern of Luzzi and Gerraughty (18) was examined. It was the intention of this study to develop a means to encapsulate solids through complex coacervation and to determine:

(1) the effects of varying the starting $\mathrm{pH}$, the starting temperature, the quantity of denaturant, the ratio of material to be encapsulated to encapsulating agents, the final $\mathrm{pH}$, and the effect of certain surfactants and deflocculants on the permeability of capsule shell when in contact with gastrointestinal fluids; and

(2) to develop a method for the evaluation of the effect of such variation on the system. This study was designed so that the susceptibility of the capsule wall to the action of gastrointestinal fluids could be determined. 


\section{EXPERIMLNOA-}

PREPARATION OF MICROCAPGYES

The basic procedure exploy ad by Iuzzi ard Gerrangtery (18) for the preparation of microcapsuies was $25=d$. The primary ericapsulating solutions were made by dissolving 3.0 Gm. of a cacia and $3.0 \mathrm{Gm}$. of gelatin separately in $100 \mathrm{ml}$. of pursied water at $55^{\circ} \mathrm{C}$. The acacia used was powdered Acacia, U.S.P.; the geiatir used was 300 bloom pigskin gelatin ${ }^{2}$ with an isoelectric foint at pH 8.0 .

A $20 \%$ sodium hydroxide solvition was uesd co adjust the starting $\mathrm{pH}$ of the solutions to 6. 5. Acacia farticles in slicion a re negatively charged and at this $\mathrm{pH}$ the gelatin particles are safficiently negative so that they will not interact with the acacia.

An emulsion was formed by adding $12 \mathrm{ml}$. of oil to the acacia solution. The gelatin solution was ther added to the emulsion, with gentle stirring.

The $\mathrm{pH}$ of the mixture was then adjustod to 4.5 by tie dropwise addition of Diluted Hydrochloric Acid, U. S. F., while scirring. At this $\mathrm{pH}$, the gelatin particles were postuively charged and were attracted to the negative acacia particles. The combined particles coalesced about the oil droplets erd isolated them from the rest of the

(a) The American Agricultural Chemical Company, Detroit, Michigan 
system.

At this point, $10 \mathrm{ml}$. of Formaldenyde solution, U.S. P., were added to the mixture and it was cooled to $10^{\circ} \mathrm{C}$. by immersion in an ice bath. The pH was then adjusted to a final pil of 9.0 by the dropwise addition of $20 \%$ sodium hydroxide solution. The addition of the formaldehyde denatured the soagulated gelatin-acacia complex and entrapped the oil droplets more permanently than before. Chilling of the coacervate helped to set the gelatin-acacia film, making it even less permeable. The $\mathrm{pH}$ adjustment also enhanced this effect.

The mixture was then diluted to approximately $400 \mathrm{ml}$. with distilled water and then filtered through filter paper. The wet mass was firmly wrapped in blotting paper to remove some of the excess mois ture. The resulting soft, rubbery mass was then passed through a 20 mesh screen and dried at $50^{\circ} \mathrm{C}$. for 24 hours. The dilution of the mixture facilitated filtration and allowed removal of some of the excess formaldehyde. The precipitate, afier being dried, was coarsely granular.

The above procedure was altered in the following ways:

(1) the starting $\mathrm{pH}$ was varied between 5.0 and 7.0 ;

(2) the ratio of material to be encapsulated to encapsulating materials (dry weight) was varied from 2/o through 20/6;

(3) the quantity of formaldehyde solution was varied from $1 \mathrm{ml}$. to $20 \mathrm{ml}$. for each $100 \mathrm{ml}$. of $3 \%$ gelatin dispersion; 
(4) the starting temperature was varied from $34^{\circ} \mathrm{C}$. to $42^{\circ} \mathrm{C}$.;

(5) the final $\mathrm{pH}$ was varied from 6.5 to 8.8 ; and,

(6) solid particles, all of which passed chrough a U. S. P. 60 mesh screen, rather than oil droplets, were encapsulated.

In addition, Tween 20 and Darvan 7 were added in various quantities to the aqueous phase prior to the addition of the solid. In order to minimize the degradation of pentobarbituric acid, the temperature at which the capsules were dried was reduced from $50^{\circ} \mathrm{C}$. to $40^{\circ} \mathrm{C}$. All data reported in the section dealing with results are averages of duplicate determinations of two or more samples.

\section{CHOICE OF MATERIALS}

The primary objective of this research was to determine whether or not a solid particle could be encapsulated by this particular process. Preliminary investigation brought forth the facts that:

(1) the solid to be encapsulated should be insoluble, or nearly so, in the system;

(2) the solid particles should be readily dispersible in either gelatin or acacia solution;

(3) the solids should contribute no surfactant qualities;

(4) the solid should be quickly soluble when exposed to the proper solvent;

(5) the solid should not degrade appreciably when exposed to 
aqueous systems for several hours;

(6) the solid should preferably be of a pharmaceutical nature.

The following solids were chosen and encapsulated: colloidal sulfur ${ }^{b}$, special flowers of sulfur ${ }^{c}$, aspirin anhydride (recrystallized from ethyl acetate solution to a M.P. of $\left.81^{\circ} \mathrm{C} .-83^{\circ} \mathrm{C}.\right)^{\mathrm{d}}$, Acetophenetidin, U.S.P., barbituric acide, lycopodium spores ${ }^{e}, D D D T^{f}$, pentobarbituric acid (M. P. $\left.127^{\circ}-128^{\circ} \mathrm{C}.\right)^{\mathrm{g}}$, and carbon black ${ }^{\mathrm{h}}$.

Since sulfur was available in a variety of particle sizes and because it seemed to conform to all of the otk $€ r$ requirements, several samples of microcapsules containing it were prepared. However, considerable difficulty was encountered when attempts were made to assay the sulfur capsules. Although it first appeared that sulfur could be assayed by a simple gravimetric method, it was found that when it was encapsulated and still wet from immersion in gastrointestinal fluids, the sulfur was, at best, only slowly extractable by carbon disulfide. This was true even when the capsules were previously crushed by mechanical means.

(b) Sulfidal ${ }^{\mathrm{R}}$, Heyden Chemical Corp., New York 17, New York

(c) Stouffer Chemicall Co., 380 Madis on Ave., New York 17, New York

(d) The Upjohn Co., Kalamazoo, Michigan

(e) Amend Drug and Chemical Co., 117 East 24th St., New York, 10, New York

(f) 1, 1, 1-trichloro-2, 2-bis (p-chlorophenyl) ethane, Technical Grade, Matteson, Coleman \& Beli, East Rutherford, New Jersey

(g) "Acid Nembutal," Abbott Laboratories, North Chicago, Illinois

(h) "UCET" Acetylene Black 50\% Compressed, Union Carbide Corp., Olefin Division, 270 Park Ave., New York, New York 
Aspirin anhydride offered the advantages trat it was less soluble than acetylsalicylic acid and that a prolonged xelease dosage form would probably prove commercially valuable. However, its stability to hydrolysis was not sufficient for the conditions of this project. Lycopodium spores and carbon black were encapsulated in an attempt to obtain more informative photomicrographs. However, neither of these substances could be assayed by a simple method. DDT, on the other hand, would have had to be extracted (as was sulfur) from aqueous media to a non-aqueous media before assays could be carried out.

The choice was therefore narrowed to barbituric acid and pentobarbituric acid. In the case of both barbiturates the advantage was apparent from the fact that both were insoluble in acid aqueous media but soluble, as their salts, in alkaline aqueous media.

Since, at that time, an in-vivo assay was contemplated and because the hypnotic effect of pentobarbituric acid is shorter than that of barbituric acid, the former, rather than the latter, was chosen to demonstrate the effect of the variables discussed earlier. This choice, however, limited the range over which certain of the variables could be tested. It became obvious, for example, that the starting hydrogen ion concentration must be kept above that at which significant quantities of pentobarbituric acid would be soluble. 


\section{METHOD OF EVALUATION OF MICROCAPSULES}

The method used to evaluate the susceptibility of the coacervate shell to the action of U.S.P. simulated gastrointestinal fluids ${ }^{i}$ was based principally on the ability of the fluids to expose and/or extract the encapsulated material. In order to determine the degree of destruction or permeability, or both, caused by the gastrointestinal fluids, a spectrophotometric method of assay was devised.

The microcapsules were prepared in the manner previously described and $0.25 \mathrm{Gm}$. samples of the dried capsules were exposed to gastric and intestinal fluids. The samples were first exposed consecutively, then separately to $100 \mathrm{ml}$. of gastric fluid and $100 \mathrm{ml}$. of intestinal fluid, employing a Burrell Wrist Action Shaker ${ }^{j}$.

In the first instance, the samples remained in contact with $100 \mathrm{ml}$. of gastric fluid for 0.5 hours, were filtered, and the filter paper and remaining sample were then transferred to $100 \mathrm{ml}$. of intestinal fluid; the filter paper was broken up prior to immersion in intestinal fluid. A $1.0 \mathrm{ml}$. sample was withdrawn through a cotton pledget after one hour exposure to intestinal fluid and, after two hours, the intestinal fluid was removed from the sample by filtration.

In the second instance, the samples were allowed to remain in contact with the gastric fluid for 0.5 hours. Duplicate samples were

(i) U.S.P.XVI, pp. 1072-73

(j) Burell Corp., Pittsburg, Pennsylvania 
prepared and allowed to remain in contact with intestinal fluid for onehalf and one hour periods.

The removal of the sample from gastrointestinal fluids was preceded in each instance by the adjustment of $\mathrm{pH}$ to 9.25. If the sample were to remain in a fluid for further extraction, the $\mathrm{pH}$ was again adjusted to official (U.S.P.) suggested values for that fluid. Diluted Hydrochloric Acid, U.S. P. and $20 \%$ sodium hydroxide solution were used for the adjustments.

Pentobarbituric acid has a pKa of $8.11(21)$ and, therefore, at $\mathrm{pH} 9.1$ the ratio of sodium pentobarbital to pentobarbituric acid becomes ten to one. Spectrophotometric studies of solutions of sodium pentobarbital indicated that adsorption increased with increased $\mathrm{pH}$ values and that at $\mathrm{pH} 9.0$, as may be predicted by theory, a gradual decrease in the slope of the curve occurred. Since pH values of 9.25 could be achieved with relative accuracy $( \pm 0.05 \mathrm{pH}$ units) and ease, and since a great majority of the solute is in the salt form at this $\mathrm{pH}$, this was the $\mathrm{pH}$ at which all liquid filtrates were compared.

The liquid filtrates, after exposure to the gastric fluid, were assayed for content of active constituent as were the liquid filtrates after exposure to intestinal fluid. The solutions were scanned for wavelength of maximum absorption using a recording spectrophotometer ${ }^{k}$. A broad peak was found with a maximum at 241 to $242 \mathrm{~m} \mu$.

(k) Bausch \& Lomb "Spectronic 505," Bausch \& Lomb Optical Co., Rochester, New York 
Beer's Law plots ${ }^{1}$ were prepared using a Beckman spectrophotometerm. The concentration of the liquid filtrates obtained by the extraction methods already described, were determined by comparing their respective Beer's Law plots to the absorbance observed.

The total quantity of pentobarbituric acid in each sample was found by disintegrating a known weight of capsules in a Virtis blender ${ }^{\mathrm{n}}$ with a known volume of distilled water at $\mathrm{pH} 9.25$, the sample was filtered and the resulting liquid adjusted, if necessary, to $\mathrm{pH} 9.25$. Aliquots were prepared and spectrophotometric data were collected which, when compared to the Beer's Law Plot of Figure III (p. 23), yielded the information from which the calculations for total pentobarbituric acid content were carried out.

(1) See figures on pages 21, 22 and 23.

(m) Beckman D.U. Spectrophotometer, Beckman Instruments, Inc., Fullerton, California

(n) Virtis "45," Precise Products Corp., Racine, Wisconsin 


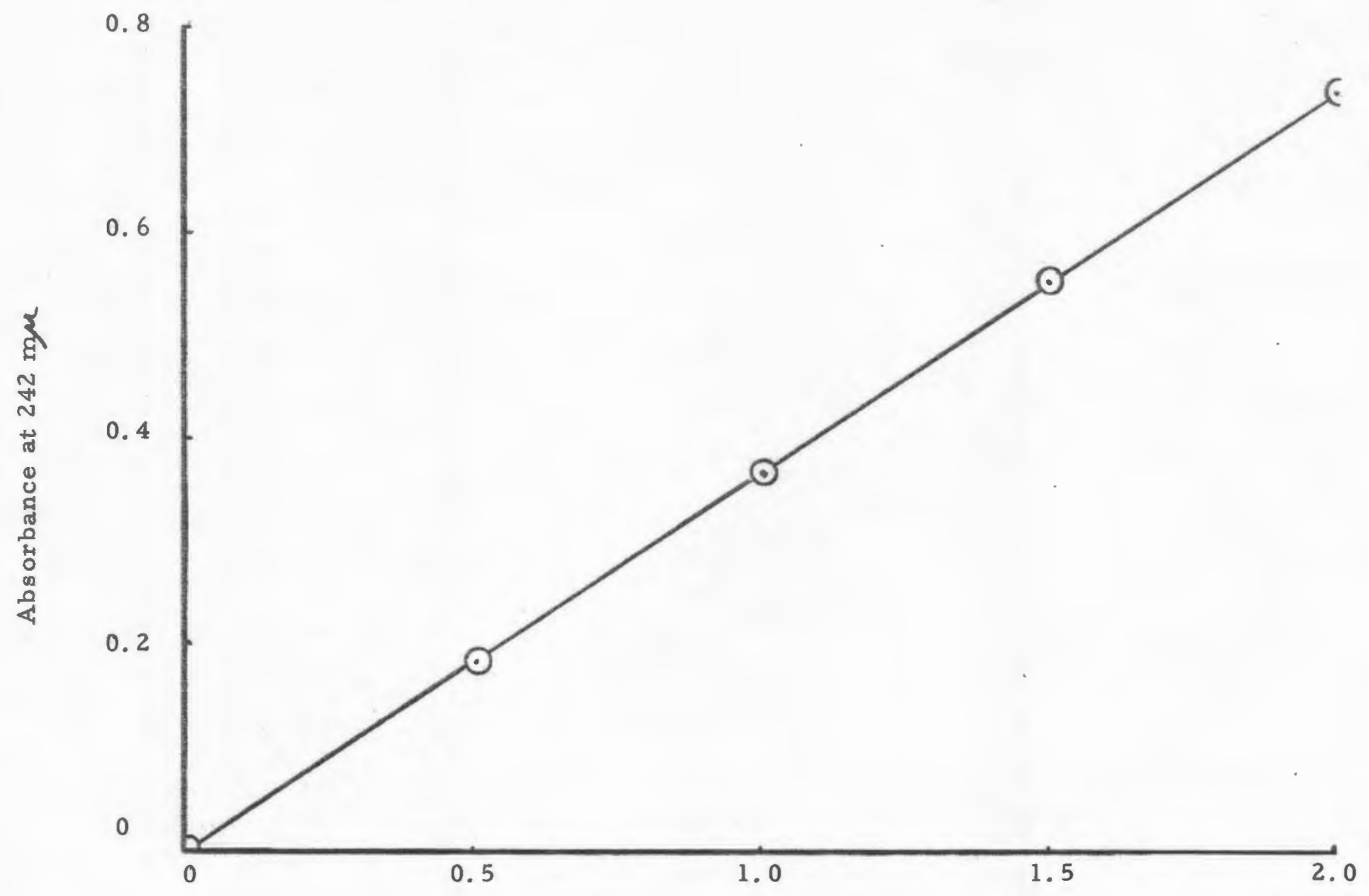

$\%$ Sodium Pentobarbital $\times 10^{-3}$

Figure 1. Beer's Law Plot of Sodium Pentobarbital in 1\% Gastric Fluid at $\mathrm{pH} 9.2$. 


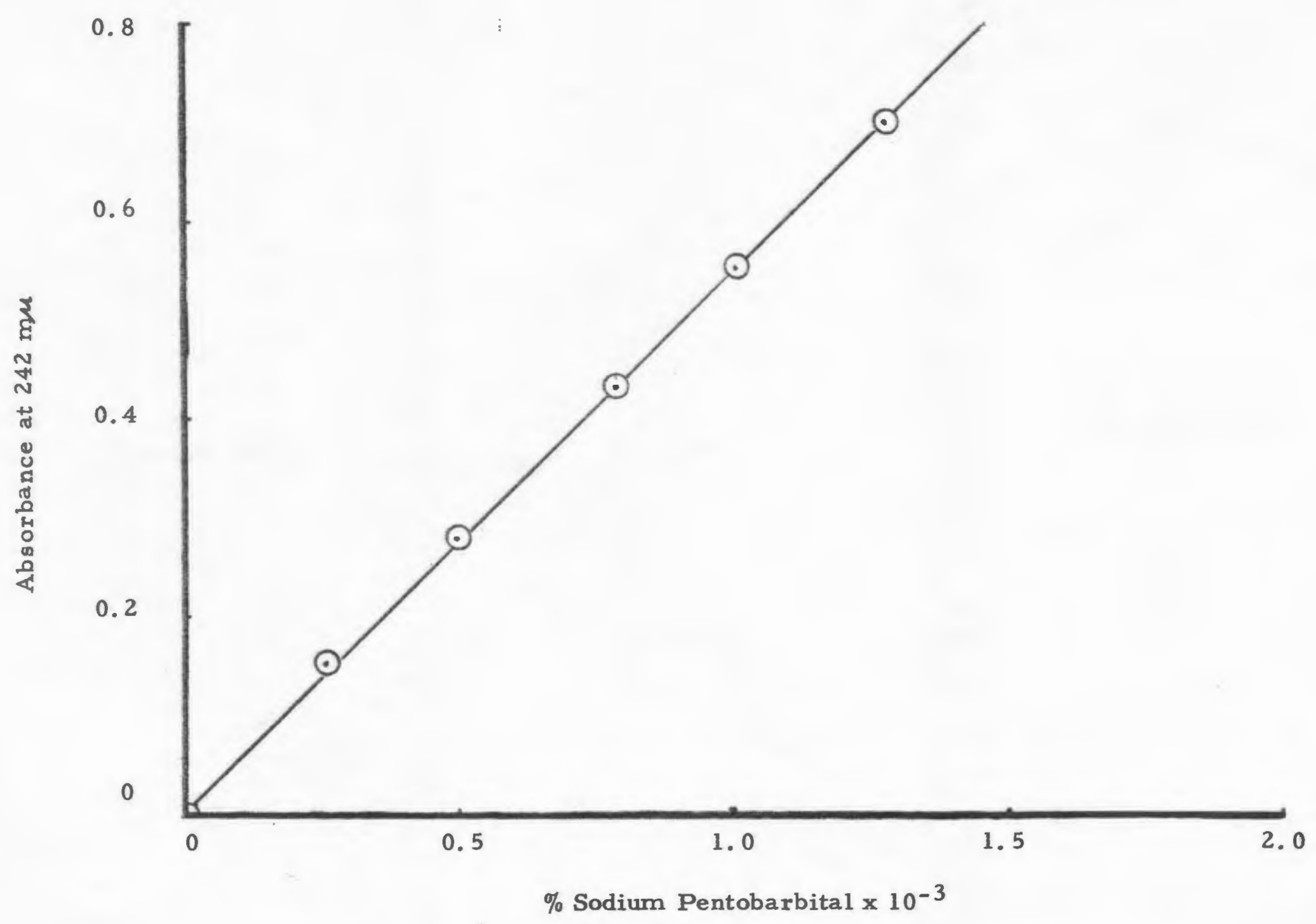

Figure 2. Beer's Law Plot for Sodium Pentobarbital in $1 \%$ Intestinal 


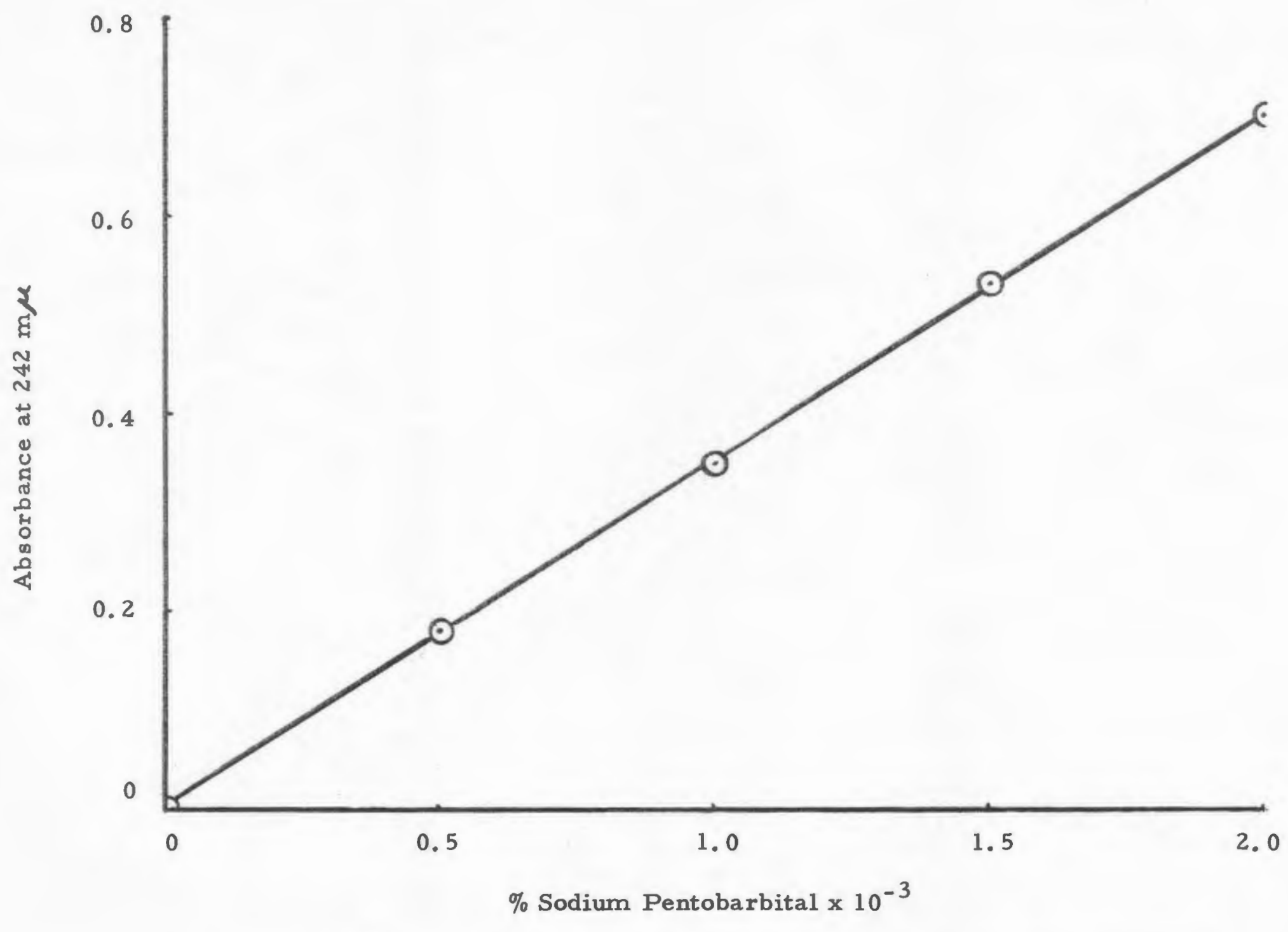

Figure 3. Beer's Law Plot for Sodium Pentobarbital in $1 \%$ Empty Capsules $\stackrel{N}{w}$ Ground in Vitric "45" Blender. 


\section{RESULTS}

\section{EFFECT OF STAR TING $\mathrm{PH}$ ON MICROCAFSULES}

Each sample in this series was prepared by a method designed to determine the effects of different starting hydrogen ion concentrations on the microencapsulation of pentobarbituric acid. That is, all aspects of the preparation of each sample remained constant throughout with the exception that the starting $\mathrm{pH}$ was varied from $\mathrm{pH} 5.0$ through $\mathrm{pH} 7.0$.

Two factors were primarily responsible for the choice of these limits. Firstly, it was observed that systems prepared using only gelatin and acacia became slightly cloudy even at $\mathrm{pH}$ values just above $\mathrm{pH} 5.0$, an indication that the point of complete coacervation was being approached so that the lowest practical starting $\mathrm{pH}$ was established to

be 5.0 . Secondly, since the salt-acid ratio of sodium pentobarbitalpentobarbituric acid increased from 1.26 at $\mathrm{pH} 7.0$ as the $\mathrm{pH}$ increased and since the salt was soluble in alkaline aqueous media, the examination of microencapsulation at starting $\mathrm{pH}$ values greater than 7.0 was not practical.

A series of samples ranging from $\mathrm{pH} 5.0$ to $\mathrm{pH} 7.0$ was prepared and $0.25 \mathrm{Gm}$. of each were assayed in the manner previously described. Table I shows that, throughout the entire series, the maximum 
TABI,E I

EFFECT OF STARTING $\mathrm{pH}$ ON THE \% OF PENTOBARBITURIC ACID EXTRACTED FROM MICROCAPSULES EXXPOSED TO GASTROINTESTINAL FLUIDS*

$\begin{array}{lllll}\text { Starting pH } & \begin{array}{l}\text { after 1/2 } \\ \text { hr. in } \\ \text { gastric } \\ \text { fluid }\end{array} & \begin{array}{l}\text { after } 1 \\ \text { hr. in } \\ \text { fluid }\end{array} & \begin{array}{l}\text { hrs. in } \\ \text { intestinal } \\ \text { fluid }\end{array} & \begin{array}{l}\text { total in } \\ \text { gastric and } \\ \text { intestinal } \\ \text { fluids }\end{array} \\ 5.0 & 33.8 & 15.9 & 24.0 & 57.8 \\ 5.3 & 27.0 & 14.8 & 26.9 & 53.9 \\ 6.0 & 30.1 & 13.3 & 23.6 & 53.7 \\ 6.5 & 23.7 & 10.9 & 29.3 & 53.0 \\ 7.0 & 30.5 & 13.3 & 24.0 & 54.5\end{array}$

*All values expressed as \% of total pentobarbituric acid found in microcapsules.

Note: After removal of gastric fluid the samples were transferred to intestinal fluid. 
difference in per cent of total of pentobarbituric acid released after 2.5 hours of exposure to gastro-intestinal fluids was only 4.8. The difference in per cent released was somewhat greater (9.9) after one-half hour exposure to gastric fluid alone. Table II indicates that after one hour exposure to intestinal fluid the maximum difference in total per cent released was 3.1. Under all the test conditions, the samples seemed to remain in the same relative positions with respect to acid released.

\section{EFFECT OF STAR TING TEMPERA TURES ON MICROCAPSULES}

Gelatin-acacia systems, in the concentrations used for this project, became gels at slightly above room temperature but became less viscous as the temperature of the systems was raised. For this reason and since the solubility of pentobarbituric acid increased with increas ing temperature, it was desirable to examine the effects on microencapsulation by varying the starting temperature.

Tables III and IV show that the range of starting temperatures employed was between $34^{\circ} \mathrm{C}$. and $42^{\circ} \mathrm{C}$. In all cases observed, except after 0.5 hours in gastric fluid, the per cent of pentobarbituric acid that was released was found to be at a maximum at $34^{\circ} \mathrm{C}$. starting temperature and reached a minimum at $37^{\circ} \mathrm{C}$. starting temperature.

EFFECT OF RATIO OF SOLID TO ENCAPSULA TING MATERIALS

During preliminary studies, microscopic examination of micro- 
TABLE' II

EFFECT OF STARTING pH ON THE \% OF PENTOBARBITURIC ACID EXTRACTED FROM MICROCAPSULES EXPOSED

TO INTESTINAL FLUID*

\begin{tabular}{lcc} 
Starting pH & 27.5 & after $1 \mathrm{hr}$. \\
\hline 5.0 & 25.8 & 28.0 \\
5.3 & 18.4 & 24.5 \\
6.0 & 22.4 & 26.5 \\
6.5 & 25.3 & 24.9 \\
7.0 & & 25.2
\end{tabular}

* All values expressed as $\%$ of total pentobarbituric acid found in microcapsules. 
TABLE III

EFFECT OF STARTING TEMPERATURE ON THE \% OF PENTO-

BARBITURIC ACID EXTRACTED FROM MICROCAPSULES

EXPOSED TO GASTROINTESTINAL FLUIDS*

\begin{tabular}{cllll}
$\begin{array}{c}\text { Starting } \\
\left.\text { Temperature ( }{ }^{\circ} \mathrm{C} .\right)\end{array}$ & $\begin{array}{l}\text { after } 1 / 2 \\
\text { hr. in } \\
\text { gastric } \\
\text { fluid }\end{array}$ & $\begin{array}{l}\text { after } 1 \\
\text { hr. in } \\
\text { intestinal } \\
\text { fluid }\end{array}$ & $\begin{array}{l}\text { after } 2 \\
\text { hrs. in } \\
\text { intestinal } \\
\text { fluid }\end{array}$ & $\begin{array}{l}\text { total in } \\
\text { gastric and } \\
\text { intestinal } \\
\text { fluids }\end{array}$ \\
\hline 34 & 44.3 & 24.4 & 27.6 & 71.9 \\
36 & 37.8 & 16.4 & 25.3 & 63.1 \\
37 & 36.8 & 13.2 & 22.0 & 58.8 \\
40 & 34.8 & 19.2 & 26.3 & 61.1 \\
42 & 38.8 & 18.9 & 26.8 & 65.6
\end{tabular}

*All values expressed as $\%$ of total pentobarbituric acid found in microcapsules.

Note: After removal of gastric fluid the samples were transferred to intestinal fluid. 
TABLE IV

EFFECT OF STAR TING TEMPERATURE ON THE \% OF PENTOBARBITURIC ACID EXTRACTED FROM MICROCAPSULES

EXPOSED TO INTESTINAL FLUID *

\begin{tabular}{llc}
\hline Starting Temperature & after $1 / 2 \mathrm{hr}$, & after $1 \mathrm{hr}$. \\
34 & 32.4 & 35.6 \\
36 & 28.3 & 32.9 \\
37 & 25.6 & 30.8 \\
40 & 27.9 & 33.1 \\
42 & 29.8 & 35.0 \\
\hline $\begin{array}{l}\text { All values expressed as \% of total pentobarbituric acid found } \\
\text { in microcapsules. }\end{array}$
\end{tabular}


capsule systems revealed what appeared to be unfilled coacervate droplets (Photograph III, page 51). This onservation, together with the assumption that there may be a practic $₫ 1$ limit to the quantity of a solid that can be added to a given system, prompted examination of systems employing different ratios of solids to encapsulating agents. The results arrived at, using starting temperature as a variable, proved to be the most predictable. The series consisted of ratios ranging from 4. $0 \mathrm{Gm}$. of pentobarbituric acid to $6 \mathrm{Gm}$. total dry weight of encapsulating materials $(4 / 6)$, through $20.0 \mathrm{Gm}$. of acid to $6 \mathrm{Gm}$. total dry weight of encapsulating materials $(20 / 6)$. With the exception of the variable, as noted, all conditions within a series remained unchanged. Tables V and VI show that, after assay, the per cent of total acid which was released from the samples increased as the ratio of solid to encapsulating material increased. Table V, it should be noted, also shows that the increase in per cent released, from one to two hour exposures to intestinal fluid, decreased as the ratio increased.

\section{EFFECT OF DIFFERENT QUANTITIES OF DENATURANT ON MICRO- CAPSULES}

To determine the effects of varying quantities of denaturant added to the system, a series of samples was prepared in which the volume of $37 \%$ formaldehyde solution was varied from one to $20 \mathrm{ml}$. for each $100 \mathrm{ml}$. of $3 \%$ gelatin solution. All other aspects of preparation were maintained constant throughout the series. 
TABLE V

EFFECT OF RATIO ON THE \% OF PENTOBARBITURIC ACID EXTRACTED FROM MICROCAPSULES EXPOSED TO GASTROINTESTINAL FLUIDS*

\begin{tabular}{|c|c|c|c|c|}
\hline Ratio & $\begin{array}{l}\text { after } 1 / 2 \\
\text { hr. in } \\
\text { gastric } \\
\text { fluid }\end{array}$ & $\begin{array}{l}\text { after } 1 \\
\mathrm{hr} . \text { in } \\
\text { intestinal } \\
\text { fluid }\end{array}$ & $\begin{array}{l}\text { after } 2 \\
\text { hrs. in } \\
\text { intestinal } \\
\text { fluid }\end{array}$ & $\begin{array}{l}\text { total in } \\
\text { gastric and } \\
\text { intestinal } \\
\text { fluids }\end{array}$ \\
\hline $4 / 6$ & 28.7 & 13.3 & 24.0 & 42. 7 \\
\hline $8 / 6$ & 36.8 & 13.2 & 22.0 & 58.8 \\
\hline $12 / 6$ & 39.1 & 18.4 & 26.6 & 65.7 \\
\hline $16 / 6$ & 40.2 & 26.1 & 30.7 & 70.9 \\
\hline $20 / 6$ & 45.2 & 26.2 & 29.1 & 74.3 \\
\hline
\end{tabular}


TABLE VI

EFFECT OF RATIO ON THE \% OF PENTOBARBITURIC ACID EXTRACTED FROM MICROCAPSULES EXPOSED TO INTESTINAL FLUID*

\begin{tabular}{lcc} 
Ratio & 26.6 & after $1 \mathrm{hr}$. \\
\hline $4 / 6$ & 25.6 & 28.2 \\
$8 / 6$ & 39.5 & 31.2 \\
$12 / 6$ & 35.5 & 38.5 \\
$16 / 6$ & 41.4 & 41.2 \\
$20 / 6$ & 52.3 \\
\hline & * All values expressed as \% of total pentobarbituric acid found \\
in microcapsules.
\end{tabular}


Formaldehyde acts as a denaturant to harden and fix in place the wet gelatinous shell; and in order to test this effect microencapsulation was attempted within the stated range. Tables VII and VIII show that $1 \mathrm{ml}$. and $2 \mathrm{ml}$. quantities of the formaldehyde solution were insufficient to effect collection of the samples. At a volume of $4 \mathrm{ml}$. of formaldehyde solution the samples became collectable and continued to be collectable throughout the remaining range of the series. An interesting observation is that, during initial exposure to either gastric or intestinal fluids, the per cent of pentobarbituric acid released from the capsules was greatest in those samples to which the largest quantity of formaldehyde had been added. Table VII also shows that when the samples were transferred from gastric fluid to intestinal fluid the quantity of acid which was found in the latter decreased with increasing quantities of formaldehyde.

\section{EFFECT OF FINAL pH ON MICROCAPSULES}

Pentobarbituric acid is very soluble at $\mathrm{pH}$ values greater than 8. 0 , and is also relatively insoluble at acid $\mathrm{pH}$ values. Considering that a $\mathrm{pH}$ value of 9.0 was previously considered optimum (18) for the final $\mathrm{pH}$, it was desirable to determine what effect would occur if the final $\mathrm{pH}$ was varied.

A series of samples was prepared with final $\mathrm{pH}$ values ranging between 6.5 and 8.8. Tables IX and X show that after initial exposure 
TABLE VII

EFFECT OF FORMALDEHYDE ON THE \% OF PENTOBARBITURIC ACID EXTRACTED FROM MICROCAPSULES EXPOSED TO GASTROINTESTINAI FLUIDS*

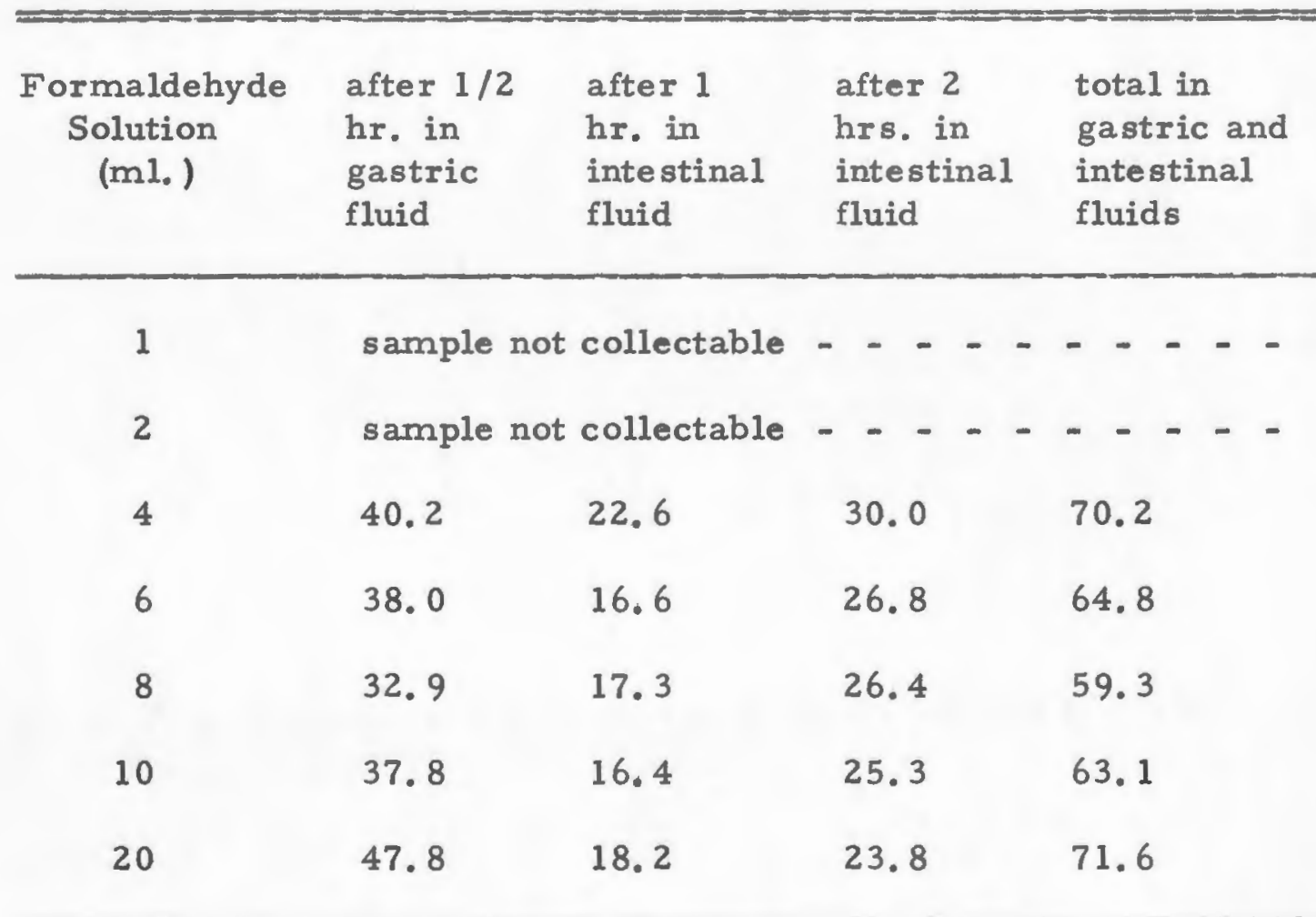

*All values expressed as \% of total pentobarbituric acid found in microcapsules.

Note: After removal of gastric fluid the samples were transferred to intestinal fluid. 
TABLE VIII

EFFECT OF FORMALDEHYDE ON THE \% OF PENTOBARBITURIC

ACID EXTRACTED FROM MICROCAPSULES EXPOSED TO INTESTINAL FLUIDS*

\section{Formaldehyde}

(ml)

after $1 / 2 \mathrm{hr}$.

after $1 \mathrm{hr}$.

$\begin{array}{lcc}1 & \text { sample not collectable }-\ldots+\ldots \\ 2 & \text { sample not collectable }-\ldots & - \\ 4 & 27.3 & 38.8 \\ 6 & 24.4 & 36.3 \\ 8 & 23.7 & 32.3 \\ 10 & 28.3 & 32.9 \\ 20 & 27.3 & 40.5\end{array}$

*All values expressed as \% of total pentobarbituric acid found in microcapsules. 
TABLE IX

EFFECT OF FINAL pH ON THE \% OF PENTOBARBITURIC ACID EXTRACTED FROM MICROCAPSULES EXPOSED TO GASTROINTESTINAL FLUIDS*

\begin{tabular}{lllll} 
Final pH & $\begin{array}{l}\text { after 1/2 } \\
\text { hr. in } \\
\text { gastric } \\
\text { fluid }\end{array}$ & $\begin{array}{l}\text { after } 1 \\
\text { hr. in } \\
\text { intestinal } \\
\text { fluid }\end{array}$ & $\begin{array}{l}\text { after } 2 \\
\text { hrs. in } \\
\text { intestinal } \\
\text { fluid }\end{array}$ & $\begin{array}{l}\text { total in } \\
\text { gastric and } \\
\text { intestinal } \\
\text { fluids }\end{array}$ \\
\hline 6.5 & 27.0 & 14.7 & 23.5 & 50.5 \\
7.0 & 23.7 & 28.4 & 29.3 & 53.0 \\
7.5 & 29.4 & 13.1 & 22.4 & 51.8 \\
8.0 & 28.6 & 17.7 & 27.2 & 55.8 \\
8.8 & 36.7 & 33.7 & 36.0 & 72.7 \\
\hline
\end{tabular}

*All values expressed as \% of total pentobarbituric acid found in microcapsules.

Note: After removal of gastric fluid the samples were transferred to intestinal fluid. 
TABLE X

EFFECT OF FINAL pH ON THE \% OF PENTOBARBITURIC ACID EXTRACTED FROM MICROCAPSULES EXPOSED TO INTESTINAL FLUID*

\begin{tabular}{lcc}
\hline Final pH & after $1 / 2 \mathrm{hr}$. & after $1 \mathrm{hr}$. \\
\hline 6.5 & 27.5 & 28.5 \\
7.0 & 22.4 & 24.9 \\
7.5 & 26.2 & 31.9 \\
8.0 & 25.5 & 29.0 \\
8.8 & 31.4 & 33.9 \\
\hline * All values expressed as $\%$ of total pentobarbituric acid found \\
in microcapsules.
\end{tabular}


to gastric and intestinal fluids the per cent of acid released at $\mathrm{pH} 7.0$ was less than that released at FH 6.5. Thereafter, a gradual increase from the low at $\mathrm{pH} 7.0$ was noted throughout the remainder of the series.

Table IX indicates that, in assays carried out after one and two hour periods on samples transferred from gastric fluid to intestinal fluid, the per cent of pentobarbituric acid extracted was erratic, with a slight tendency to increase as the final pH. was increased. Table IX also shows, however, that the overall per cent extracted increased with increasing final $\mathrm{pH}$

\section{EFFECT OF TWEEN 20 ON MICROCAHSULES}

Luzzi and Gerraughty (18) showed that Tween 20 in concentrations of $2 \%$ completely inhibited the encapsulation of mineral oil; it was thought that the orientation of Tween 20 molecules at the oil-water interface acted to prevent shell forming coacervate droplets from becoming oriented at the interface of the oil. The preparation of a series of microcapsules was undertaken in an attempt to establish the effect on microencapsulation of Tween 20 in systems employing solid rather than liquid particles.

In this series the per cent of Tween 20 included in the aqueous phase was varied from zero to $0.0142 \%$, the starting $\mathrm{pH}$ was 6.0 , the starting temperature was $40^{\circ} \mathrm{C} ., 8 \mathrm{Gm}$. of pentobarbituric acid were 
TABLE XI

EFFECT OF TWEEN 20 ON THE: \% OF PENTOBARBITURIC ACID EXTRACTED FROM MICROCAPSULES EXPOSED TO GASTROINTESTINAL FLUIDS*

\begin{tabular}{|c|c|c|c|c|}
\hline $\begin{array}{c}\text { Tween } 20 \\
(\%)\end{array}$ & $\begin{array}{l}\text { after } 1 / 2 \\
\text { hr. in } \\
\text { gastric } \\
\text { fluid }\end{array}$ & $\begin{array}{l}\text { after } 1 \\
\text { hr. in } \\
\text { intestinal } \\
\text { fluid }\end{array}$ & $\begin{array}{l}\text { after } 2 \\
\text { hrs. in } \\
\text { intestinal } \\
\text { fluid. }\end{array}$ & $\begin{array}{l}\text { total in } \\
\text { gastric and } \\
\text { intestinal } \\
\text { fluids }\end{array}$ \\
\hline - - & 34.8 & 19.2 & 26.3 & 61.1 \\
\hline 0.0001 & 35.0 & 17.5 & 26.8 & 61.8 \\
\hline 0.0002 & 33.9 & 18.5 & 27.0 & 60.9 \\
\hline 0.0006 & 32.7 & 20.1 & 28.3 & 61.0 \\
\hline 0.0071 & 34.4 & 19.7 & 28.2 & 62.6 \\
\hline 0.0142 & 40.7 & 20.0 & 26.1 & 66.8 \\
\hline
\end{tabular}

*All values expressed as \% of total pentobarbituric acid found in microcapsules

Note: After removal of gastric fluid the samples were transferred to intestinal fluid. 
included, a volume of $10 \mathrm{ml}$. of formaldehyde solution was added, and the final pH was 7.5. Table XI shows that under these conditions there was no significant change in the per cent of pentobarbituric acid releas. ed, with the exception that, at the highest concentration of 'Tween 20 , there seemed to be an increase in the per cent of acid released.

\section{EFFECT OF DARVAN 7 ON MICROCAPSULES}

Since the solid particles of pentobarbituric acid tended to settle out of suspension and were at times difficult to disperse, the dispersing agent Darvan 7 was added to three separate series. Also, since preliminary work indicated that Darvan 7 was basic $(\mathrm{pH} 8.5-9.0)$ in the concentrations used, it was desirable to determine what effects changing $\mathrm{pH}$ would have on the activity of the dispersant. The three series differed in that the lowest pH values employed were $4.0,4.8$, and 3.5.

The samples of Table XII were prepared in an identical manner to those in the Tween 20 series, the only difference being that Darvan 7 rather than Tween 20 was added. At the lowest concentrations of Darvan 7 there seemed to be less acid extracted by gastrointestinal fluids than even those samples prepared with no dispersant; thereafier, the per cent of acid released became greater with increasing additions of Darvan 7.

Where the samples of Table XIII correspond to the Darvan 7 concentrations of those in Table XII, they are identical, with the exception 
TABLE: XII

EFFECT OF DARVAN 7 ON THE \% OF PENTOBARBITURIC ACID EXTRACTED FROM MICROCAPSULES EXPOSED TO

GASTROINTESTINAL FLUIDS*

\begin{tabular}{lllll}
\hline $\begin{array}{l}\text { Darvan } 7 \\
(\%)\end{array}$ & $\begin{array}{l}\text { after } 1 / 2 \\
\text { hr. in } \\
\text { gastric } \\
\text { fluid }\end{array}$ & $\begin{array}{l}\text { after } 1 \\
\text { hr. in } \\
\text { intestindl } \\
\text { fluid }\end{array}$ & $\begin{array}{l}\text { after } 2 \\
\text { intestinal } \\
\text { fluid }\end{array}$ & $\begin{array}{l}\text { gastric and } \\
\text { intestinal } \\
\text { fluids }\end{array}$ \\
\hline-19.8 & 19.2 & 26.3 & 61.1 \\
0.0195 & 30.2 & 18.4 & 24.6 & 54.8 \\
0.0290 & 35.0 & 20.1 & 25.6 & 60.6 \\
0.0580 & 39.1 & 22.1 & 27.1 & 66.2 \\
0.1160 & 34.7 & 19.7 & 28.1 & 62.8 \\
0.1450 & 43.0 & 21.5 & 26.2 & 67.2 \\
0.1740 & 38.0 & 23.1 & 30.7 & 68.7
\end{tabular}

* All values expressed as \% of total pentobarbituric acid found in microcapsules.

Note: After removal of gastric fluid the samples were transferred to intestinal fluid. 
TABI.E XIII

EFFECT OF DARVAN 7 ON THE \% OF FENTOBARBITURIC ACID EXTRACTED FROM MICROCAFSULES EXPOSED TO

GASTROINTESTINAL FLUIDS*

\begin{tabular}{|c|c|c|c|c|}
\hline $\begin{array}{l}\text { Darvan } 7 \\
\quad(\%)\end{array}$ & $\begin{array}{l}\text { after } 1 / 2 \\
\text { hr. in } \\
\text { gastric } \\
\text { fluid }\end{array}$ & $\begin{array}{l}\text { after } 1 \\
\text { hr. in } \\
\text { intestinal } \\
\text { fluid }\end{array}$ & $\begin{array}{l}\text { after } 2 \\
\text { hrs. in } \\
\text { intestinal } \\
\text { fluid }\end{array}$ & $\begin{array}{l}\text { total in } \\
\text { gastric and } \\
\text { intestinal } \\
\text { fluids }\end{array}$ \\
\hline-- & 42.2 & 21.7 & 25.9 & 68.8 \\
\hline 0.029 & 43.5 & 21.2 & 25.7 & 69.2 \\
\hline 0.116 & 45.3 & 16.3 & 24.7 & 70.0 \\
\hline 0.174 & 48.5 & 28.4 & 30.7 & 79.2 \\
\hline \multicolumn{5}{|c|}{$\begin{array}{l}\text { All values expressed as } \% \text { of total pentobarbituric acid found } \\
\text { in microcapsules. }\end{array}$} \\
\hline
\end{tabular}


that the lowest $\mathrm{pH}$ in the former was 4.8 rather than 4.0 . Table XIII shows that there was a greater release of pentobarbituric acid as the concentration of Darvan 7 was increased and also that all of the samples of Table XIII released a greater percentage of acid than the corresponding members of Table XII.

All of the samples within the series found in Table XIV were prepared in a manner similar to those of the Tween 20 group above with the exception that the lowest $\mathrm{pH}$ was at $\mathrm{pH} 3.5$ rather than at 4.0 . Table XIV shows that samples were not collectable until the second increment of Darvan 7 had been added; with the addition of the second increment of the dispersant, they became collectable. Increases in the concentration of Darvan 7 beyond the point at which the samples became collectable could not be studied.

\section{FORMULATION OF FAST AND SLOW RELEASE MICROCA PSULES}

Using the information gathered from Tables I through XII, an attempt was made to formulate microcapsules which would release all or nearly all of the pentobarbituric acid which they contained. An attempt was also made to formulate microcapsules which would retain more than $50 \%$ of their original content of acid after 2.5 hours exposure to gastrointestinal fluids. Samples of both formulations were prepared and they were subjected to the gastrointestinal fluids, as previously described. 
TABLE XIV

EFFECT OF DARVAN 7 ON THE \% OF PENTOBARBITURIC ACID EXTRACTED FROM MICROCAPSULES EXPOSED TO GASTROINTESTINAL FLUIDS*

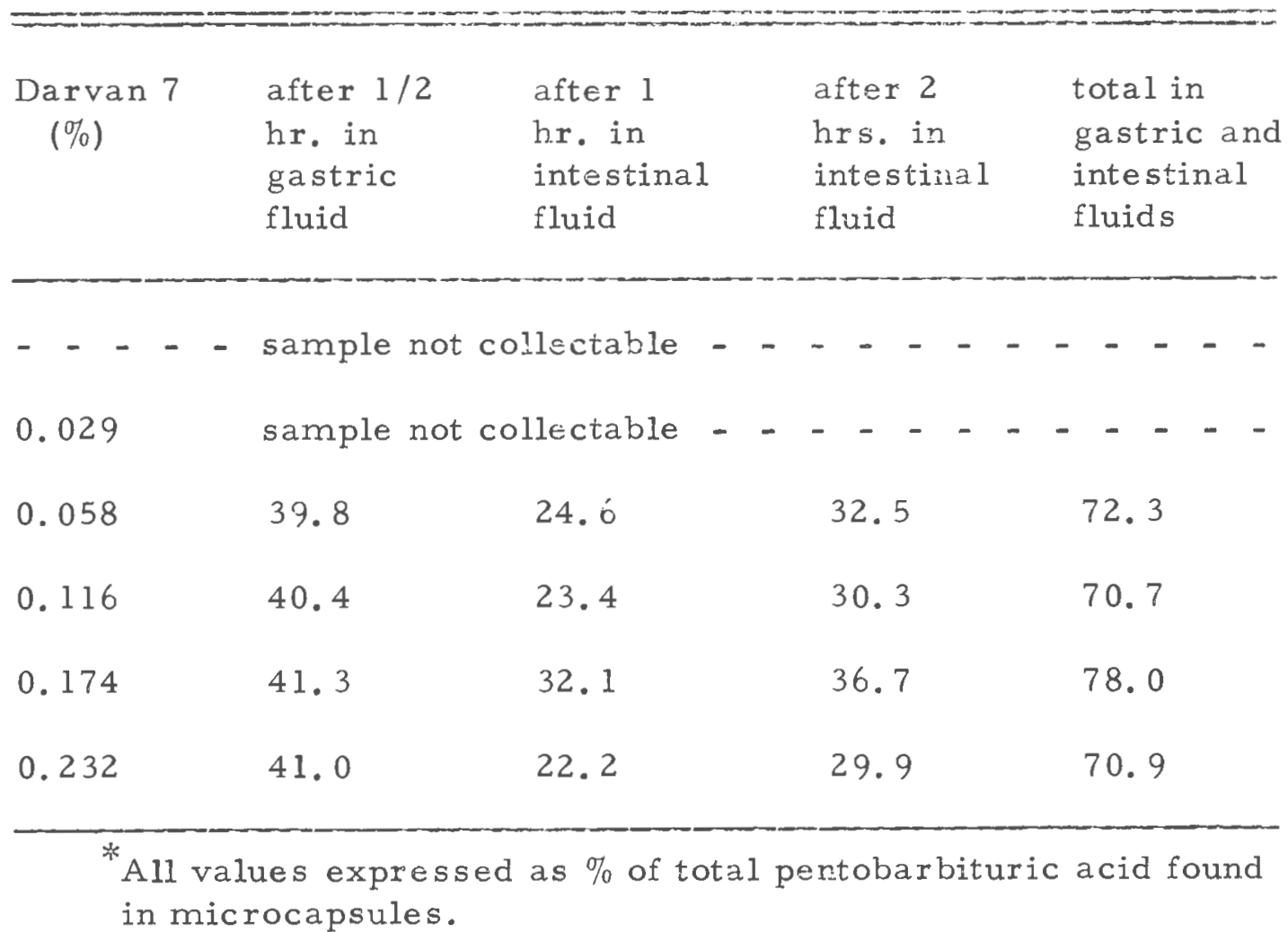

Note: After removal of gastric fluid the samples were transferred to intestinal fluid. 
Samples for fast release microcapsules were prepared using the following conditions: the starting $\mathrm{pH}$ was 5.0, the starting temperature was $34^{\circ} \mathrm{C}$, the ratio of pertobarbituric acid to encapsulating agents was 20/6, four milliliters of formaldehyde solution was added for each $100 \mathrm{ml}$. of $3 \%$ gelatin solution and, the final pH was 8.8 .

Samples for slow release microcapsules were prepared using the following conditions: the starting $\mathrm{pH}$ was 6.0 ; the starting temperature was $37^{\circ} \mathrm{C} . ;$ the ratio of acid to encapsulating agents was $4 / 6$; eight milliliters of formaldehyde solution was added; and the final $\mathrm{pH}$ was 6.5 .

The results of assays for fast release microcapsules revealed that 47. $3 \%$ of the drug was extracted after one-half hour exposure to gastric fluid, $30.1 \%$ after being transferred to intestinal fluid and remaining immersed for one hour, $31.2 \%$ extracted after two hours in intestinal fluid, for a total of $78.5 \%$ released after two and one-half hours exposure to gastrointestinal fluids.

The results of assays for slow release microcapsules revealed that $37.7 \%$ of the drug was released during one-half hour exposure to gastric fluid, $16.0 \%$ released after being transferred to intestinal fluid and being immersed for one hour and $21.5 \%$ extracted after two hours in contact with intestinal fluid, for a total of $56.2 \%$ released after two and one-half hours exposure to gastrointestinal fluids.

In the fast release samples there was a difference of $1.1 \%$ in total 
per cent acid extracted between the one and two hour exposure periods to intestinal fluid, whereas there was a difference of $5.5 \%$ acid extracted under the same conditions for the slow release samples. Although the per cent of pentobarbituric asid released after the two and one-half hour assay period fell somewhat short of the goal of this experiment, there seemed to be a significant difference in the per cent of acid released between the two types of samples. It should be pointed out that although the results found in Table I indicate that a starting $\mathrm{pH}$ of 6.5 was optimum for slow release microcapsules, a $\mathrm{pH}$ of 6.0 was utilized since the over-all difference between the values was not significant and since the acid is less soluble at lower $\mathrm{pH}$ values.

\section{MICRO-PHOTOGRAPHY OF MICROCAPSULES}

It is the intent of this section to clarify (through photographs) the action of the gelatin-acacia complex as an encapsulating agent as well as to underscore the effects of Tween 20 and Darvan 7 on microencap sulation. The solid, in this case, pentobarbituric acid, was encapsulated in the prescribed manner and photomicrographs were taken of the product after filtration and prior to drying.

The equipment employed consisted of an Exakta VX-11 $\mathrm{a}^{\circ}$ camera

(o) Exakta Camera Co., Bronx River Road, Bronxville, New York 
mounted on a Spencer binocular microscopep. All exposures were for 4 seconds using Panatomic-x film by Kodak. The magnification in each photograph was determined by comparison, at similar conditions, to a standard ruled slideq. A magnification statute accompanies each photograph.

Photograph I shows a dispersion of pentobarbituric acid particles in a $3 \%$ gelatin solution. It can be seen that the particles are quite well dispersed. The slight haze surrounding the particles is due to the movement of the particles probably caused by evaporation of water.

Photograph II is typical of groups of microcapsules found when there is an optimum relationship between solid particles and encapsulating agents. All particles are encapsulated and it can be seen that, in some cases, the capsules have fused together. It is also apparent that in some cases small groups of solid particles are encompassed by a single capsule.

Photograph III depicts both filled and unfilled microcapsules. The encapsulated solid in this case is DDT. No explanation of capsule shape can be given at this time.

Tween $20(0.0071 \%)$ was added to the system of Photograph IV. Both encapsulated and unencapsulated particles are visible.

(p) American Optical Company, Buffalo 15, New York (q) Bousch and Lomb Optical Co., Rochester, New York 
Photographs of systems containing less surfactant were prepared and, although not shown, suggested a progressive interferrence with encapsulation as Tween 20 concentration was increased.

Photographs V, VI and VII are of systems containing $0.019 \%$, $0.029 \%$ and $0.116 \%$ of Darvan 2 respectively. In Photograph V it can be seen that the particles were not well dispersed and that large groups of particles seem to have gathered together to form a large group or groups of capsules. This may account for the decreased release of pentobarbituric acid at this concentration of Darvan 7 (Table XII, p. 41).

Photograph VI was made from microcapsules to which $0.029 \%$ Darvan 7 had been added and shows elongated capsules filled with solid particles. The elongation of capsules seemed to be typical when moderate quantities of this dispersant were used. A comparison of the shell thickness of the overall capsules to the shell thickness of capsules of previous photos would seem to indicate that high concentrations of the dispersant tent to decrease wall thickness.

Photograph VII was made of microcapsules containing $0.116 \%$ Darvan 7. Although the enlargement in this case was less than in preceding ones, it can be seen that the solids are in smaller groups, that the capsule shells are quite thin, and that some capsules are not filled. 


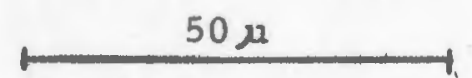

Photegraph I

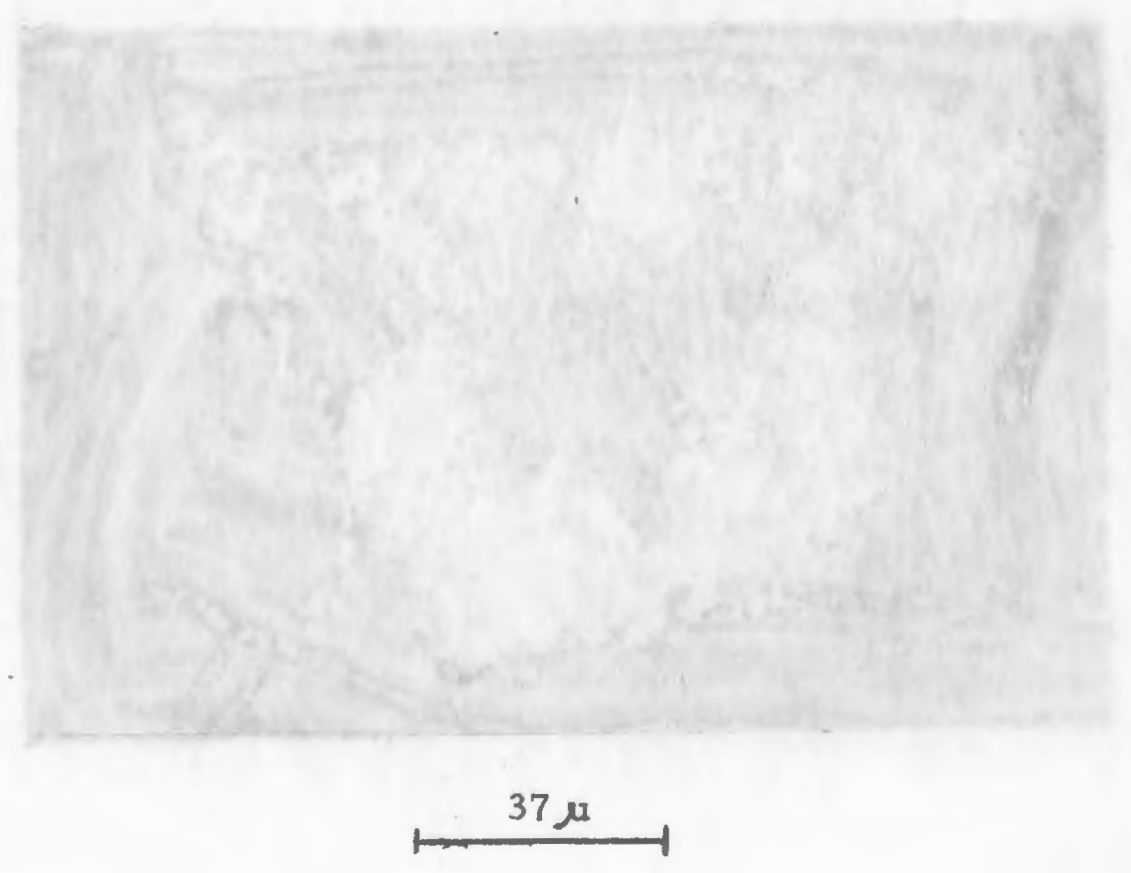

Photograph II 

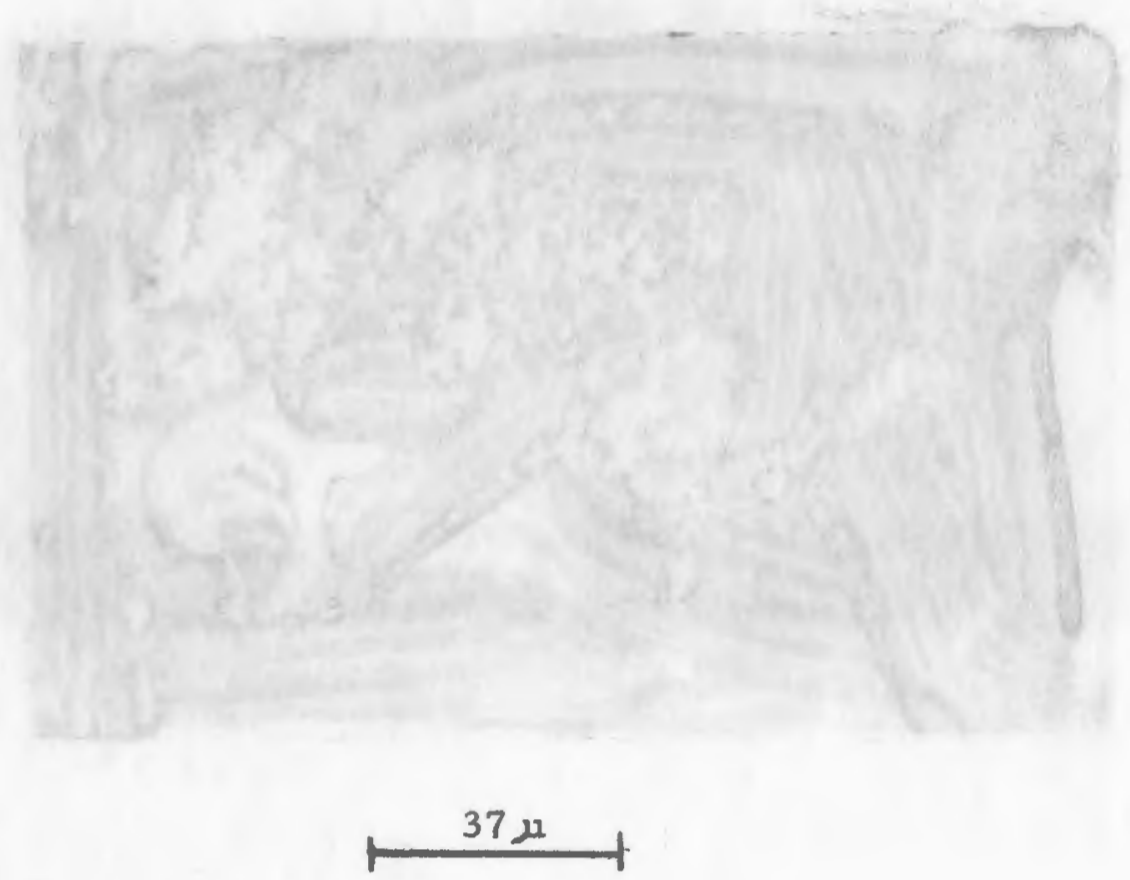

Photograph III

$37 \mu$

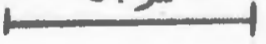

Photograph IV 


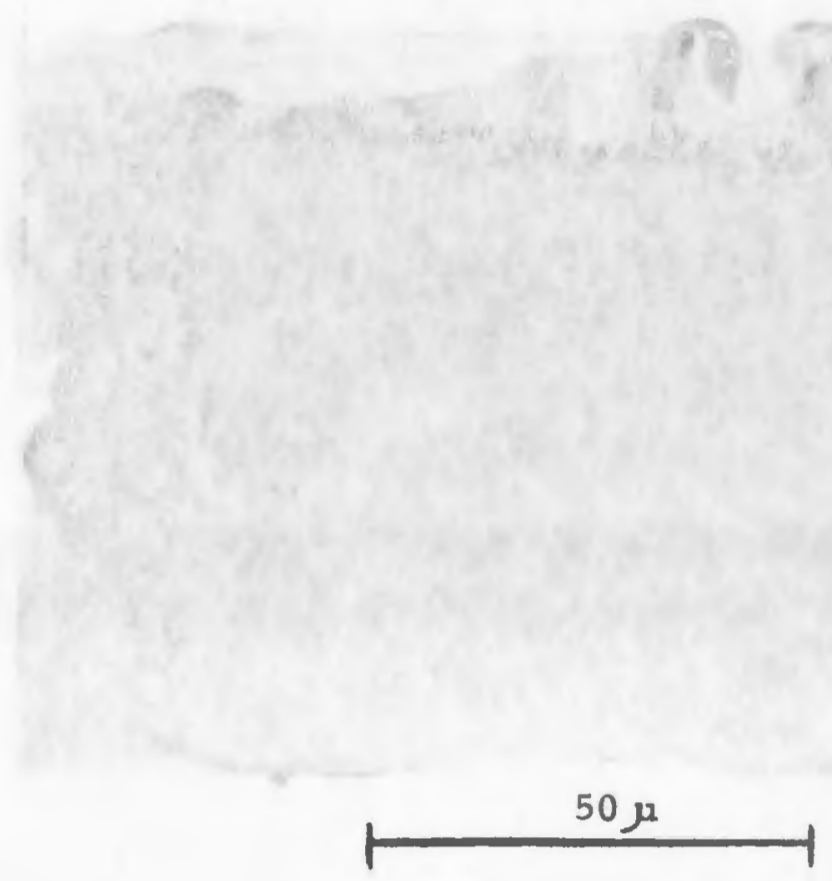

Photograph V

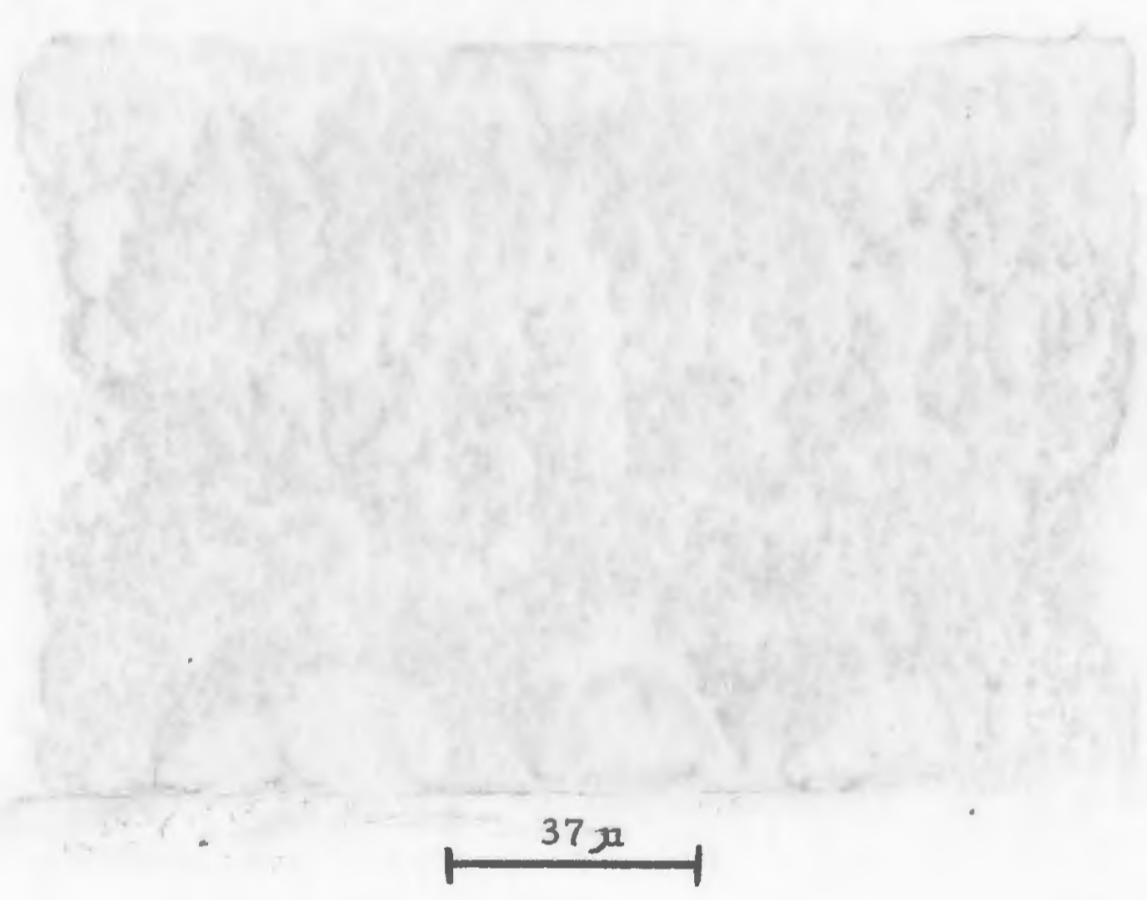

Photograph VI 


\section{DISCUSSION}

Microencapsulation of finely divided solids occurs when coacervate droplets form about the solid particles, but the mariner in which the actual encapsulation ocrurs is not clear. The fcllowing are two possible methods by which encipsulation may occur. Eirst, the capsule formation may occur in one step, that is, only one coacervate droplet may be required to encompass each particle. If this is the case, one would suspect that the size of the particle or the method of preparation of the droplet would be of major consideration.

Second, the capsule formation may occur as the result of the agglomeration of many small coacervate droplets about the solid particles to form a closed capsule which may or may not be porous.

In botk cases the coacervate capsule may hi: corsidered to be prior to drying, made up zi hydrated, Hoicia wa lal. When the microcapsule shells are dehydrated, the thickness of the coacervate shell is reduced and the whole particle is reduced in size, although there is no change ir. the size of the encapsulated solid.

Possible applications of this form of ricroencapsulation to pharmaceuticals led to an interest in the possitility of encapsulating 


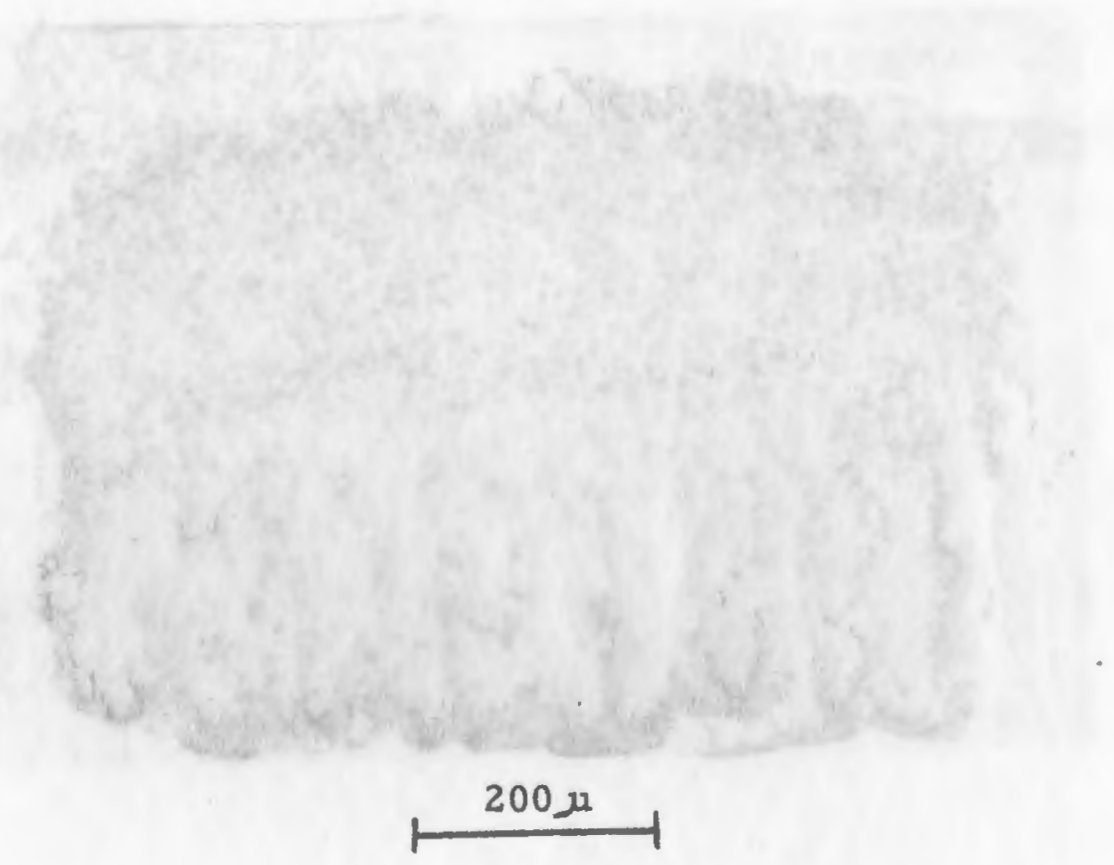

Photograph VII 
solids and to the evaluation of some ispects of the system used to prepare the capsules. The solids whick were encapsulated by this method include: Colloidal sulfur, special flowers of sulfur, aspirin anhydride, acetophenetidin, barbituric acid, lycopodium spores, DDT, pentobarbituric acid, and carbon black. Pentobarbituric acid was employed for the collection of all quantitative data presented in this thesis. The specific variables chosen for study included starting $\mathrm{pH}$, starting temperature, ratio of encapsulated material to encapsulating materials, quantity of denaturant, and the final pH.

It was desirable to obtain some degree of controlled variation of these properties, and in this respect all samples within a given group were prepared utilizing the same conditions with the exception that one of the above variables was altered. However, comparison of results between series is not valid since factors other than the indicated variable may have been altered. It should be explained that at no tirne during the preparation of a given series did any of the variable conditions chosen for examination exceed the limits set forth in the series designed to examine the effects of the variable.

The method of Luzzi and Gerraughty (18) was chosen since this investigator was familiar with it and since it offered the opportunity to evaluate a unique systern for the microencapsulation of solids. 
EFFECT OF STARIING PH ON MICROCA PSULES

A study of the effect of starting pH on the per cent of pentobarbituric acid released from the various microcapsule samples which had been exposed to gastric and intestinal fluids (Table I, p. 25) reveals that the quantity of acid released over a 2.5 hour period did not differ significantly. When the samples were exposed only to intestinal fluid (Table II, p. 27) for a one hour period, there again seemed to be no significant difference in the protection offered, however, examination of the data for one-half hour periods in both gastric fluid and intestinal fluid indicates a greater variation in the per cent of total acid released.

The per cent extracted after one-half hour in intestinal fluid is probably the least reliable of all the data collected, since during this time interval there was no digestion of protein and the only probable reactions were a combination of hydration and leaching. In light of the above, it would seem likely that as hydration of the shell approached completion, the results would become more reliable as well as more reproducible. This was found to be the case with samples exposed only to intestinal fluid for one hour periods. This supposition was further substantiated by the assay results obtained from the consecutive immersions of samples in gastric and intestinal fluids.

The per cent pentobarbituric acid extracted after immersions in gastric fluid for one-half hour indicated no clear trend. It was expected that the highest per cent releases would occur at pH 5.0 and 
$\mathrm{pH} 7.0$ and although this was the case, the difference between these two values and the intervening values was not of such a nature that a definitive judgement could be made. A.t a starting $\mathrm{pH}$ of 5.0 , coacervation was probably partially complete prior to the addition of the solid particles, in which case the ratio of encapsulated to encapsulating material would have, in effect, been increased. It is quite clear from Tables V and VI (pp. 31 and 32 ) that as this ratio increases the per cent of solid released increases.

At a starting $\mathrm{pH}$ of 7.0 the solubility of pentobarbituric acid, as its salt, is theoretically greater than at the other $\mathrm{pH}$ values. Therefore, it is possible to suggest interference with the microencapsulation process, at $\mathrm{pH} 7.0$, by virtue of the presence of too high a salt concentration (10). The possibility also exists that, once converted to its solubilized form, the active constituent could have been adsorbed or entrapped by the gelatin or acacia or both and subsequently released to the gastric fluid more rapidly than if solubilization had not occurred.

EFFECT OF STARTING TEMPERATURE ON MICROCAPSULES

As may be seen from Tables III and IV, the relative position of each sample, as to the per cent of pertobarbituric acid extracted, was found to remain the same after all time periods. A maximum in per cent of acid extracted was found when the starting temperature was 
$34^{\circ} \mathrm{C}$. It may be that, at this temperature, ths system of gelatin and acacia was sufficiently viscous to inhibit the free movement of either the colloidal particles, which is necessary for codcervation, or of the formed coacervate droplets, which may be necessary if microencapsulation is to occur.

After a minimum was reached, an increase was observed in per cent of total acid extracted as the starting temperature was increased. This was probably due to the salt-like effect of the greater quantity of acid in solution at the higher temperatures. It could also be due, in part, to the entrapment by the encapsulating medium of the solubilized acid, thus causing faster initial release rates. The latter speculation is not, however, substantiated by the $x$ esults shown in Table IV (p. 29), when these results are compared to the results of similar extraction procedures.

In light of the above discussion, it is possible to suggest that the lower per cent release of acid at the starting temperature of $37^{\circ} \mathrm{C}$. was due to a combination of (sufficiently low) viscosity and relatively low concentration of acid in solution; and converse reasoning would probably hold for the higher per cent release at $34^{\circ} \mathrm{C}$. 
EFFECT OF THE RATIO OF PENTOBARBITURIC ACID TO ENCAPSULATING MATERIALS

The results of this study indicate that, within the range of ratios used, pentobarbituric acid was extracted from microcapsules more rapidly, in all cases, as the ratio of acid to encapsulating agents was increased.

A comparison of the per cent of pentobarbituric acid extracted in gastric fluid with the per cent released after the ore and two hour exposures to intestinal fluid (Table V, p. 31) indicates that the low ratio samples release a higher percentage of remaining acid with increasing time. It would be interesting to determine whether or not the low ratio samples would continue to release a greater percentage of the remaining acid with the passage of time, however, the available data precludes such a determination.

These results would, however, seem to underscore the theory of microencapsulation in which many coacervate droplets agglomerate about the particle. In order to conform to this theory, the preparations with lower ratios would probably have multiple layers of droplets while preparations with higher ratios would have fewer layers.

\section{EFFECT OF FORMA LDEHYDE ON MICROCAPSULES}

The effect of formaldehyde on the permeability of microcapsules was determined by varying the quantity of formaldehyde solution added to the system during the preparation of samples. When no 
formaldehyde solution was added, and with quantities of up to $2 \mathrm{ml}$. per $100 \mathrm{ml}$. of gelatin solution, the samples seemed to melt together either on reaching room temperature or upon drying at $40^{\circ} \mathrm{C}$. with the addition of $4 \mathrm{ml}$, or more, of formaldehyde solution the samples maintained a typical appear nce throughout the preparation procedures.

Because formaldehyde is a denaturant of protein, it is essential to this method of microencapsulation, a fact that seems to be substantiated by the difficulty encountered in collection of samples to which little or no formaldehyde was added.

The release of acid from capsules to which $8 \mathrm{ml}$. of formaldehyde solution had been added was at a minimum when exposed to gastrointestinal fluids. When the volume of formaldehyde solution was varied by $2 \mathrm{ml}$. in either direction, an increase in the quantity of acid extracted was observed. As the quantity of formaldehyde solution was varied further, a greater increase in the per cent of released acid was observed.

The increase in the per cent of acid released at the low formaldehyde concentration was probably due to two factors both of which could result from inadequate denaturization. First, the gelatinacacia shell might not have been sufficiently denatured, thus promoting a partial solubilization of coacervate droplets during the washing procedure to create a thinner or more porous shell; and second, the droplets might not have been solubilized duxing washing but may 
have been made less impervious to the action of gastrointestinal fluids through lack of adequate denaturization.

Microscopic observations of samples, prior to drying, throughout the entire range of this series indicate no appreciable difference in the size of the microcapsules. This observation would seem to suggest that an increased susceptibility to gastrointestinal fluids was responsible for the rise in per cent of acid extracted from samples to which small quantities of formaldehyde had been added.

The increased per cent of acid that was extracted when greater volumes of formaldehyde solution were added to the system was probably due to a cracking of the capsule shell on drying. This cracking, which resulted in porous capsules, may have resulted from excessive denaturization.

\section{EFFECT OF FINAL $\mathrm{pH}$ ON MICROCAPSULES}

The samples of this series seemed to show at tendency for the microcapsules to give up more of the encapsulated solid as the final $\mathrm{pH}$ was increased. Since a high final $\mathrm{pH}$ acts to fix the coacervate droplets in place about the particle to be encapsulated and since pentobarbituric acid is quite insoluble at $\mathrm{pH} 6.5$, it was expected that a relatively high per cent of acid would be extracted at this pH. It was also expected that because of the solubility of the acid at high $\mathrm{pH}$ values, a maximum per cent extracted would be observed at a final 
pH 8. 8. The latter expectation was borne out in the results found in Table IX (p. 36).

The results shown in this table would sesm to indicate that capsules prepared at a final pH 7.0 were exisacted to a lesser degree by gastric fluid and to a greater degree by insestinal fluid than the rest of the series, with the exception of the final sample.

At final $\mathrm{pH} 6.5$ the capsule shells appear to have been broken down more readily by gastric fluid than at $\mathrm{pH} 7.0$. The possibility also exists that at $\mathrm{pH} 7.0$ the capsules were more firmly fixed and less porous than at $\mathrm{pH} 6.5$. It is also possible that at $\mathrm{pH} 7.0$ the capsules were digested extensively by the gastric fluid ... to such a degxe€ as to eventually allow faster leeching eventually, but not so excessively as to expose the solid completely - thus making the capsule shells much more permeable to extraction when placed in intestinal fluids.

The higher rates of extraction at final pH values above 7.0 could have resulted from an increased acid solubility; and the retention of the solubilized acid by the capsule wall during the drying procedure, followed by rapid release to the extraction fluids. At final pH 8.8 the quantity of acid solubilized is probably much greater than at other values used; the salt formed at $\mathrm{pH} 8.8$ may have acted to reverse the coacervation process causing a general weakening of the capsule shell and resulting in greater quantities of extracted. 


\section{CONCLUSIONS}

On the basis of the previous work and the results reported in this study, the following conclusions may be drawn -

1. Solids, such as pentobarbituric acid, which are relatively insoluble in aqueous systems, can be successfully encapsulated and well protected.

2. In the coacervation process used, starting pH values below 5. 0 , microencapsulation of pentobarbituric acid is inhibited.

3. The strength of the capsule shell can be controlled by changing, either individually or combinations of: the starting temperature, the ratio of encapsulable to encapsulating materials, the quantity of formaldehyde added, and the final pH.

4. Surfactants or dispersants, in sufficient concentration, increase the rate of release of encapsulated solids to gastrointestinal fluids.

5. The end results of encapsulation may be elucidated by the use of microphotographic techniques.

In order to clarify some of the aspects of this problem, further work in the following areas is recommended.

1. Experiments should be designed that would apply the results 
obtained in this investigation to the formation of time release medication.

2. Controlled combinations of the variables tesied here should be examined.

3. Other problems of encapsulation by this method, such as lowest encapsulating $\mathrm{pH}$, should be examined more thoroughly.

4. In order to determine the effect of the order of mixing, other surfactants and deflocculants as well as those already used, should be introduced at various points during the preparation of microcap sules.

5. Encapsulation should be attempted using denaturants, such as alcohol, rather than formaldehyde. 


\section{REFE:RENCES}

1. Murray, J. A. H., ed., A New English Dictionary, Vol. 2, Clarendon Press, Oxford, 1959, p. 544.

2. The Condensed Chemical Dictionary, 4th $\in$ d., Reinhold Fublishing Corp., New York, 1950, p. 178.

3. Kruyt, H. R., and Bungenbert de Jong, H. G., Proc. Koninkle. Nederland Wetenschap. , Amsterdam, 32, 1929, p. 849.

4. Kruyt, H. R., ed., Colloid Science, Vol. 2, Elsever Publishing Co., Amsterdam, 1949, p. 339.

5. Ibid., p. 250

6. Ibid., p. 250,256 .

7. Ibid., p. 341

8. Lyman, R. A., and Sprowles, J. B., હd., Textbook of Pharmaceutical Compounding and Dispensing, 2nd ed., J. B. Lippincott Co., Philadelphia, 1957, p. 296.

9. Kruyt, H. R., op. cit., p. 336.

10. Ibid., p. 349.

11. Green, B. K., and Schleiker, L., U. S. Patent 2,730,457, (1956).

12. Green, B. K., U. S. Patent 2,722, 507, (1955).

13. Green, B. K., and Schleiker, L., U. S. Patent 2,730,456, (1956).

14. Green, B. K. et al., U. S. Patent 2, 800,456, (1957).

15. Green, B. K., U. S. Patent 2,800, 458 (1957).

16. Soloway, S., U. S. Patent 3,137,631, (1964). 
17. Miller, R. E., and Anderson, J. L., J. S. Patent 3, 155,590, (1964).

18. Luzzi, L. A., and Gerraughty, R. J., J. Pharm. Sci., 53, 1964, p. 429.

19. Phares, R. E., and Sperandio, G. J., I. Pllarm. Sci., 53, 1964, p. 515 .

20. A Special Report on Microencapsulation, 1st $\in$ d. , Management Reports, 38 Cummington St., Boston, Mass.

21. Martin, A. N., Physical Pharmacy, Lea and Febiger, Philadelphia, 1960, p. 253. 